\title{
The Effect of Mobile Phone Use of Universty Students on Their Academic Success
}

\author{
Hüseyin Eriş ${ }^{1 *}$, Suzan Havlioğlu ${ }^{2}$, Miyaser Kaya ${ }^{3}$ \\ 1* Harran University, Vocational High School of Healthcare Service, Şanlıurfa, Turkey,(Orcid: 0000-0002-1685-9819)erisharran@hotmail.com \\ ${ }^{2}$ Harran University, Vocational High School of Healthcare Service, Şanliurfa, Turkey,(Orcid:0000-0001-5593-5688)suzanhavlioglu@hotmail.com \\ ${ }^{3}$ Harran University, Vocational High School of Healthcare Service, Şanlıurfa, Turkey,(Orcid: 0000-0002-4126-0488) mkaya@harran.edu.tr
}

(First received 25 May 2021 and in final form 20 September 2021)

(DOI: $10.31590 /$ ejosat.942753)

ATIF/REFERENCE: Eriş. H., Havlioğlu. S., Kaya. M. (2021). The Effect of Mobile Phone Use of Universty Students on Their Academic Success. European Journal of Science and Technology, (27), 433-438.

\begin{abstract}
The aim of this study is to determine the mobile phone use level of university students and the effect of their mobile phone use on their academic success. The study was carried out between February-March 2020 as a descriptive study in Vocational High School of Healthcare Service. The population of study consists of 2400 students that study in Vocational High School of Healthcare Service, the sample of it consists of 335 students that wanted to participate in the study. An information form and Problematic Mobile Phone Use Scale for University Students, created by reviewing literature, were used to collect data. Students averagely use mobile phones for $4.5 \pm 1.54$ hours and social media for $2.3 \pm 0.79$ hours daily. Students use their phones at the rate of $32.5 \%$ for internet and $23 \%$ of them regard spending time on mobile phone as a waste of time. According to problematic mobile phone use scale, the means of students is 62.27 , their mean is 23.50 at the deprivation sub-dimension, 13.58 at the adverse outcomes sub-dimension, 16.08 at the control problem sub-dimension and 9.08 at the interaction avoidance sub-dimension. The problematic mobile phone use scale means of students, whose academic success are above the average, was found as lower, the problematic mobile phone use scale means of students, who spend time on their phone more than 6 hours daily, was found as higher.
\end{abstract}

Key Words: University Students, Mobile Phone, Academic Success

\section{Üniversite Öğrencilerinin Cep Telefonu Kullanımlarının Akademik Başarılarına Etkisi}

Öz

Bu çalışmanın amacı üniversite öğrencilerin cep telefonu kullanım düzeyleri ile cep telefonu kullanımlarının akademik başarıları üzerine etkisinin belirlenmesidir. Çalışma Şubat-Mart 2020 tarihleri arasında Sağlık Hizmetleri Meslek Yüksekokulunda tanımlayıcı tipte bir araştırma olarak yürütülmüştür. Çalışmanın evrenini Sağlık Hizmetleri Meslek Yüksekokulunda öğrenim gören 2400 öğrenci, örneklemini ise çalışmaya katılmayı kabul eden 335 öğrenci oluşturmaktadır. Verilerin toplanmasında literatür taranarak oluşturulan bilgi formu ve Üniversite Öğrencileri için Problemli Cep Telefonu Kullanım Ölçeği kullanılmıştır. Öğrenciler günde ortalama $4.5 \pm 1.54$ saat cep telefonu ve $2.3 \pm 0.79$ saat sosyal medya kullanıyorlar. Öğrenciler cep telefonunu \% 32.5 internetten yararlanmak için kullanıyor ve \% 23 cep telefonunda vakit geçirmeyi zaman kaybı olarak değerlendiriyor. Problemli cep telefonu kullanım ölçeğine göre öğrencilerin ortalama puanları 62.27, yoksunluk alt boyutunda 23.50, olumsuz sonuçlar alt boyutunda 13.58, kontrol problemi alt boyutunda 16.08 ve etkileşimden kaçınma alt boyutunda 9.08'dir. Akademik başarısı ortalamanın üzerinde olan öğrencilerin problemli cep telefonu kullanım ölçeği puan ortalamaları daha düşük, günde 6 saatten fazla cep telefonu ile vakit geçirenlerin, problemli cep telefonu kullanım ölçeği puan ortalamaları daha yüksek bulunmuştur.

Anahtar Kelimeler: Üniversite Öğrencileri, Cep Telefonu, Akademik Başar

\footnotetext{
*Corresponding Author: erisharran@hotmail.com
} 


\section{Introduction}

Today, with the rapid development of communication technologies and the internet, their reflections on social, cultural, and economic life have begun to be felt visibly. Especially at the beginning of 2000 s, access to information, share of information, even types of creating information and interpersonal communication types have reshaped and changed due to the remarkable development of internet and mobile phone technologies, depending on the internet (Aydin, 2016). Also, internet use has become an indispensable part of life because it eases people's lives and gives them the advantage to save the time. Because of the internet, people do their several daily routines with the least physical power and cost in a short time. This network, which develops and changes day by day, has become indispensable for many people (Çiftçi, 2018).

Especially young people and university students have begun to use frequently internet and social media, mass media with easy and quick access, for academic or other purposes day by day. These tools have become not only a good source of information but also a source of other purposes such as social interactions, play, fun etc. (Diker and Taşdelen, 2017).

Approximately $66.8 \%$ of people in Turkey use the internet. The number of mobile phone subscriptions reached 77.8 million people in Turkey in 2017 (Ataş and Çelik, 2019). According to the report which was published with the name of "Digital 2019 in Turkey" - the statistics of internet and social media - prepared by We are Social and Hootsuit every year, there are 59.36 million internet users, $72 \%$ of the total population, 52 million active social media users, $63 \%$ of the total population, 44 million active mobile social media users, $53 \%$ of the total population. While $98 \%$ of adults use mobile phone; $77 \%$ of them have a smart phone. People spend approximately 7 hours on the internet in a day. On the other hand, they spend approximately 2 hours and 46 minutes on social media, 3 hours and 9 minutes on television in a day (Datareportal, 2019).

In the report, which is stated that there are 52 million social media users in total, it is pointed out that 44 million of them connect to social media via mobile devices. When the statistics of mobile users analysed, it is seen that the number is 76.3 million people which equals to $93 \%$ of population in Turkey. In addition, it is claimed in the report that mobile applications have been downloaded 2.8 billion times in total over the past year (Bal and Balc1, 2020).

The rapid increase in the use of mobile phone, which was previously thought to be as harmless or less harmful and became "smart" with the developing technology, has brought negative outcomes, especially leading to an addiction. Mobile phones which people initially get to communicate, have become an uncontrollable power with its expanding features, and in conclusion; addiction risk has arisen and this has led to dangerous behaviours. Today, an important part of smart phone users has reached a "milestone" in which they cannot control negative outcomes because of the excess use of this tool (Bal and Balc1, 2020).

In general, addiction can be defined as trying harder for certain behaviour, continuing the delightful behaviour by drifting apart from the real world, developing tolerance with the repetitive behaviours, having difficult to control behaviours and symptoms like uneasiness, which arises with the hindering of the repetition of behaviour (Noyan et al., 2015). In this regard, internet
Sence and Technology

addiction can be defined as the excess use of the internet; the signs of anger, nervousness, and tense when internet is not available; more use, namely tolerance, with the search for better equipment like better computers, tablets and phones, which have better software, quicker access; and as a result of them, underachievement, social isolation, telling lies and discussions (Chakraborty, Basu and Kumar, 2010). According to the behaviourist approach, if satisfaction is achieved as a result of behaviour or a negative situation can be overcome with behaviour, individuals can prefer this behaviour to achieve satisfaction or overcome the negative situation in future. Hence, smart phones are also addictive elements with this feature (Kuyucu, 2017).

\section{Material and Method}

\subsection{The Aim of the Study}

The aim of this study is to determine the mobile phone use level of university students and the effect of their mobile phone use on their academic success.

\subsection{The Population and Sample of Study}

The study was carried out between February-March 2020 as a descriptive study in Vocational High School of Healthcare Service. The population of study consists of 2400 students that study in Vocational High School of Healthcare Service. According to the simple random sampling method, 335 students constitute of the sample of study.

\subsection{Data Collection Tools}

Information form and Problematic Mobile Phone Use Scale for University Students, created by reviewing literature, were used to collect data.

\subsection{Problematic Mobile Phone Use Scale}

It was developed by Pamuk and Atlı in 2016 and designed to determine the status of problematic mobile phone use (MMPUS) of university students. MMPUS consists of 26 items and four subdimensions. 5-Likert scale was used to collect data in the study.

The means of sub-dimensions of MMPUS are as: Deprivation sub-dimension: 1-8, Adverse Outcomes sub-dimension: 9-15, Control Problem sub-Dimension: 16-21, Interaction Avoidance sub-Dimension: 22-26. Every item gets a point from 1 to 5, and as the points increase, problematic mobile phone use levels of students increase (Pamuk and Atl1, 2016).

Question form was applied under observation after students were informed. Data analyses were made with SPSS 20 programme. For data analysis, descriptive statistics (number, frequency, mean) were used, and for analysing the differences between groups, independent simple t-test and independent variance analysis (ANOVA) were used, and Kruskal Wallis test and correlation analysis for inapplicable values were used.

Before the study, the approval was gotten from Harran University, Social and Human Sciences Ethical Committee (08.0412020/1), Harran University, Vocational High School of Healthcare Service and participants.

\section{Findings}

Findings obtained were given in this chapter of the study. Descriptive information regarding the participant students are shown in Table 1. 
Table 1. The Distribution of Descriptive Features of Students $(N=335)$

\begin{tabular}{|c|c|c|c|}
\hline \multicolumn{2}{|l|}{ Variable } & Number & Percentage \\
\hline \multirow[t]{2}{*}{ Sex } & Male & 76 & 22.7 \\
\hline & Female & 259 & 77.3 \\
\hline \multirow[t]{2}{*}{ Age (20.28 \pm 1.69$)$} & $18-21$ & 286 & 85.4 \\
\hline & $22-34$ & 49 & 14.6 \\
\hline \multirow[t]{3}{*}{ Income } & Income is lower than expense & 123 & 36.7 \\
\hline & Income and expense are equal & 192 & 57.3 \\
\hline & Income is higher than expense & 20 & 6.0 \\
\hline \multirow[t]{2}{*}{ Employment Status } & Yes & 49 & 14.6 \\
\hline & No & 286 & 85.4 \\
\hline \multirow[t]{4}{*}{ Academic Success } & Below Average & 23 & 6.9 \\
\hline & Average & 179 & 53.4 \\
\hline & Above Average & 125 & 37.3 \\
\hline & Far Above Average & 8 & 2.4 \\
\hline \multirow[t]{2}{*}{ How long have you been using mobile phone? } & $1-5$ & 181 & 54.0 \\
\hline & $6-16$ & 154 & 46.0 \\
\hline \multirow{4}{*}{$\begin{array}{l}\text { How much time do you spend on your mobile } \\
\text { phone in a day? }(4.5 \pm 1.54)\end{array}$} & $0-1$ & 21 & 6.3 \\
\hline & $2-3$ & 111 & 33.1 \\
\hline & $4-6$ & 140 & 41.8 \\
\hline & More than 7 hours & 63 & 18.8 \\
\hline \multirow[t]{2}{*}{ Social Media Use } & Yes & 267 & 79.7 \\
\hline & No & 68 & 20.3 \\
\hline \multirow{4}{*}{$\begin{array}{l}\text { How much time do you spend on social media in a } \\
\text { day? }(2.3 \pm 0.79)\end{array}$} & $0-1$ & 42 & 12.5 \\
\hline & 2-3 Hours & 173 & 51.6 \\
\hline & 4-5 Hours & 93 & 27.8 \\
\hline & More than 6 hours & 27 & 8.1 \\
\hline \multirow{8}{*}{$\begin{array}{l}\text { Which complaints do you have depending on } \\
\text { mobile phone use? }\end{array}$} & Burning Eyes & 42 & 12.5 \\
\hline & Insomnia & 42 & 12.5 \\
\hline & Uneasiness & 22 & 6.6 \\
\hline & Forgetfulness & 42 & 12.5 \\
\hline & Headache & 43 & 12.8 \\
\hline & Tiredness & 16 & 4.8 \\
\hline & Waste of Time & 77 & 23.0 \\
\hline & Other & 51 & 15.2 \\
\hline \multirow[t]{5}{*}{ Which purposes do you use mobile phone? } & Communication & 70 & 20.9 \\
\hline & Message & 90 & 26.9 \\
\hline & Playing & 22 & 6.6 \\
\hline & Internet & 109 & 32.5 \\
\hline & Social Media & 44 & 13.2 \\
\hline
\end{tabular}

Socio-demographic data of participant students are shown in Table $1.77 .3 \%$ of them are female and the average of age is $20.28 \pm 1.69$. Students use mobile phone for averagely $4.5 \pm 1.54$ hours and social media for $2.3 \pm 0.79$ hours daily. Students use their phones at the rate of $32.5 \%$ for internet and $23 \%$ of them regard spending time on mobile phone as waste of time.

\section{Table 2. The Means of Problematic Mobile Phone Use Scale}

\begin{tabular}{|c|c|c|c|c|}
\hline Scale & Mean & SS & Min. & Max. \\
\hline Problematic Mobile Phone Use Scale & 62.27 & 22.14 & 26 & 130 \\
\hline Deprivation & 23.50 & 9.46 & 8 & 40 \\
\hline Adverse Outcomes & 13.58 & 6.39 & 7 & 35 \\
\hline Control Problem & 16.08 & 6.41 & 6 & 30 \\
\hline Interaction Avoidance & 9.08 & 4.71 & 5 & 25 \\
\hline
\end{tabular}

Problematic mobile phone use scale means of participant students are shown in Table 2. According to problematic mobile phone use scale, the mean of students is 62.27 in general, 23.50 at the deprivation sub-dimension, 13.58 at the adverse outcomes sub-dimension, 16.08 at the control problem sub-dimension and 9.08 at the interaction avoidance sub-dimension. 


\begin{tabular}{|c|c|c|c|c|c|}
\hline \multirow{2}{*}{\multicolumn{2}{|c|}{ VARIABLE }} & \multicolumn{3}{|c|}{ Problematic Mobile Phone Use Scale } & \\
\hline & & \multirow{2}{*}{$\begin{array}{c}\text { MEAN } \\
64.17\end{array}$} & \multirow{2}{*}{$\begin{array}{c}\text { SD } \\
27.34\end{array}$} & \multicolumn{2}{|c|}{ Significance } \\
\hline \multirow[t]{2}{*}{ Sex } & Male & & & \multirow[t]{2}{*}{$\mathrm{T}=.84$} & \multirow{2}{*}{$\mathrm{p}=.39$} \\
\hline & Female & 61.72 & 20.37 & & \\
\hline \multirow[t]{2}{*}{ Age } & $18-21$ & 62.04 & 21.57 & \multirow[t]{2}{*}{$\mathrm{T}=-.47$} & \multirow[t]{2}{*}{$\mathrm{p}=.63$} \\
\hline & $22-34$ & 63.65 & 25.40 & & \\
\hline \multirow[t]{3}{*}{ Income } & Income is lower than expense & 62.19 & 22.53 & \multirow[t]{3}{*}{$\mathrm{F}=.37$} & \multirow[t]{3}{*}{$\mathrm{p}=.68$} \\
\hline & Income and expense are equal & 62.75 & 21.79 & & \\
\hline & Income is higher than expense & 58.25 & 23.69 & & \\
\hline \multirow[t]{2}{*}{ Employment Status } & Yes & 60.34 & 23.11 & \multirow[t]{2}{*}{$\mathrm{T}=-.66$} & \multirow[t]{2}{*}{$\mathrm{p}=.50$} \\
\hline & No & 62.61 & 21.99 & & \\
\hline \multirow[t]{4}{*}{ Academic Standing } & Below Average & 66.56 & 22.00 & \multirow[t]{4}{*}{$\mathrm{KW}=9.81$} & \multirow[t]{4}{*}{$\mathrm{P}=.02$} \\
\hline & Average & 64.97 & 22.29 & & \\
\hline & Above Average & 58.39 & 21.67 & & \\
\hline & Far Above Average & 49.87 & 14.53 & & \\
\hline \multirow{2}{*}{$\begin{array}{l}\text { How long have you been using } \\
\text { mobile phone? }\end{array}$} & $1-5$ & 61.37 & 22.09 & \multirow[t]{2}{*}{$\mathrm{T}=-.81$} & \multirow[t]{2}{*}{$\mathrm{p}=.41$} \\
\hline & $6-16$ & 63.34 & 22.22 & & \\
\hline \multirow{3}{*}{$\begin{array}{l}\text { How much time do you spend on } \\
\text { your mobile phone in a day? }\end{array}$} & $0-2$ & 48.66 & 21.86 & \multirow[t]{3}{*}{$\mathrm{F}=17.73$} & \multirow[t]{3}{*}{$\mathrm{p}=.001$} \\
\hline & $3-5$ & 58.34 & 20.86 & & \\
\hline & More than 6 hours & 70.87 & 21.35 & & \\
\hline \multirow[b]{2}{*}{ Social Media Use } & Yes & 64.66 & 21.77 & \multirow[t]{2}{*}{$T=4.05$} & \multirow[t]{2}{*}{$\mathrm{p}=.001$} \\
\hline & No & 52.92 & 21.21 & & \\
\hline \multirow{4}{*}{$\begin{array}{l}\text { How much time do you spend on } \\
\text { social media in a day? }\end{array}$} & $0-1$ & 51.47 & 16.49 & \multirow[t]{4}{*}{$\mathrm{F}=14.47$} & \multirow[t]{4}{*}{$\mathrm{p}=.001$} \\
\hline & 2-3 Hours & 58.63 & 19.98 & & \\
\hline & 4-5 Hours & 69.02 & 24.02 & & \\
\hline & More than 6 hours & 79.03 & 21.20 & & \\
\hline
\end{tabular}

Problematic mobile phone use scale means of participant students and comparison of some variables are shown in Table 3. The problematic mobile phone use scale mean of students, whose academic success is above the average, was found as lower, the problematic mobile phone use scale mean of students, who spend time on their phone more than 6 hours daily, use social media and spend time on social media more than 6 hours in a day, was found as higher $(\mathrm{p}<.05)$.

Table 4. The Means of Problematic Mobile Phone Use Scale, Academic Success of Students and Correlation Outcomes

\begin{tabular}{|c|c|c|c|c|c|c|}
\hline & $\begin{array}{l}\text { Academic } \\
\text { Success }\end{array}$ & MMPUS & Deprivation & $\begin{array}{l}\text { Adverse } \\
\text { Outcomes }\end{array}$ & $\begin{array}{l}\text { Control } \\
\text { Problem }\end{array}$ & $\begin{array}{l}\text { Interaction } \\
\text { Avoidance }\end{array}$ \\
\hline Academic Success & 1 & & & & & \\
\hline MMPUS & $\begin{array}{l}-.164 \\
.003\end{array}$ & 1 & & & & \\
\hline Deprivation & $\begin{array}{l}-.137 \\
.012\end{array}$ & $\begin{array}{l}.849 \\
.000\end{array}$ & 1 & & & \\
\hline Adverse Outcomes & $\begin{array}{l}-.126 \\
.021\end{array}$ & $\begin{array}{l}.820 \\
.000\end{array}$ & $\begin{array}{l}.496 \\
.000\end{array}$ & 1 & & \\
\hline Control Problem & $\begin{array}{l}-.189 \\
.001\end{array}$ & $\begin{array}{l}.860 \\
.000\end{array}$ & $\begin{array}{l}.674 \\
.000\end{array}$ & $\begin{array}{l}.622 \\
.000\end{array}$ & 1 & \\
\hline Interaction Avoidance & $\begin{array}{l}-.072 \\
.192\end{array}$ & $\begin{array}{l}.704 \\
.000\end{array}$ & $\begin{array}{l}.387 \\
.000\end{array}$ & $\begin{array}{l}.648 \\
.000\end{array}$ & $\begin{array}{l}.477 \\
.000\end{array}$ & 1 \\
\hline
\end{tabular}

The means of problematic mobile phone use scale, academic success of students and correlation outcomes are shown in Table 4. As seen in the table, a statistically significant low negative relationship at $\mathrm{p}<.05$ level was found between points as a result of Pearson's Product-Moment Correlation analysis, made to determine the relationship between the points of problematic mobile phone use scale of students and their academic success. 


\section{Results and Discussion}

This study was carried out to determine whether mobile phone use of university studies has an effect on their academic success. In this study, the mean of students was found as high (62.27) according to problematic mobile phone use. A similar study was carried out by Talan, Korkmaz and Gezer (2016) and the total mean of problematic mobile phone use scale of students was found as high.

In this study, ANOVA and Kruskal Wallis test were used for the comparison of MMPUS means of students according to some socio-demographic features of students. As a result of the analysis, a statistically significant difference was not found in terms of sex, age, income, and employment status of students. There are studies that obtain similar results in the literature review. In the study, carried out by Kuyucu (2017) to determine the smart phone addiction level of university students, it was found out that there was not a statistically significant difference between groups in terms of sex and age variables of students. In the study, carried out by Talan et al. (2016) on the assessment of mobile phone addiction level of university students, it was found out that there was not a significant relationship between groups in terms of mobile phone addiction level of students according to sex, studying faculty, socio-economic status and the year they have mobile phone.

In the literature, there is a study in which it was found that there is a significant difference between groups in terms of sex and the mean of problematic mobile phone use of female students was higher (Bianchi and Phillips, 2005; Karakuyu and Ata, 2019; Yılmaz, Şar and Civan, 2015).

In terms of academic success of students, statistically significant difference between groups was found according to the variables; how long have you been using mobile phone, daily use of mobile phone, social media use and how much time do you spend time on social media in a day.

It was found that academic success of students, whose MMPUS mean is low, is higher and above the average. In other words, students with high academic success, who participated in the study, have lower MMPUS mean and higher academic success in comparison to the groups that "spend time on their phone more than 6 hours daily", "use social media" and "spend time on social media more than 6 hours".

According to the correlation analysis in the study, mobile phone use has a negative low effect on the academic success. In other words, it was found out that one-unit mobile phone use would decrease academic success at a $16.4 \%$ rate.

In literature review, similar results were found in the study regarding the effect of mobile phone use of students on their academic success. In the study, carried out by Akyıldız (2017), to analyse the relationship between the mobile phone addiction level of total 230 students, studying in English prep school in the university, and their academic success in English, a negative and statistically significant relationship was found between mobile phone addiction level of students and their academic success. With reference to the findings obtained, it was found out as the level of mobile phone addiction of students increases, the rate of academic success decreases. In the study, carried out by Seo et al. (2016), it was found that mobile phone use decreases academic success of students as well as its several negative effects. Similar results were obtained in the study, carried out by Felisoni and Godoi (2018) to determine the effect of mobile phone use on academic performance, and it was found that academic success of students decreases as mobile phone use increases. Similar results were obtained in the study carried out by Bülbül and Tunç (2018), and it was found that success of students decreases as their mobile phone use increases. In the study, carried out by Karakuyu and Ata (2019) among associate students, similar results were obtained and it was found that mobile phone use decreases academic success. In the studies, carried out by Yen et al. (2009) in Taiwan and Tavolacci et al. (2015) in France, regarding students, similar results were obtained and it was found that mobile phone use of students has negative effects on their academic success.

On the other hand, in the study, carried out by Cheng and Tzeng (2010), it was found that students who do researches regarding course subjects on the Internet are academically more successful.

When the results of this study and similar studies in the literature analysed, it was found that excess mobile phone use of students affect negatively their academic performance. By looking at the results of limited number of studies, which show that students' easy access to information and doing research regarding course subject in the era of technology would increase their academic success, it is thought that carrying out different studies for students to use efficiently their mobile phones for their academic lives and giving them education would be helpful.

\section{Reference}

Akyıldız, S. T. (2017). The Relationship between Mobile Phone Addiction and Academic Achievement in University Students, II. International Multidisciplinary Studies Congress, Ankara.

Ataş, A, H. \& Çelik, B. (2019). Smartphone Use of University Students: Patterns, Purposes and Sutiations. Malaysian Online Journal of Educational Technology. 7(2), 59 - 70.

Aydın, İ. E. (2016). A Study on Usage of Social Media among Universty Students: Anadolu University Case. Selçuk Üniversitesi Sosyal Bilimler Enstitüsü Dergisi, 16, 373 - 386.

Bal, E. \& Balcı, Ş. (2020). Smartphone Addiction: A Study on Efficacy of Personality Traits and Usage Patterns. Journal of Erciyes Communciation, 7(1), 369 - 394.

Bianchi, A. \& Phillips, J.G. (2005). Psychological Predictors of Problem Mobile Phone Use. CyberPsychology \& Behavior, 8(1), 39-51.

Bülbül, H. \& Tunç, T. (2018). Phone And Game Addiction: Scale Analysis, The Starting Age And Its Relationship With Academic Success. Suleyman Demirel University Visionary Journal, 9(21), 1-13.

Chakraborty, K., Basu, D. \& Kumar, V. (2010). Internet Addiction: Consensus, Controversies and The Way Ahead. East Asian Arch Psychiatry, 20, 123 - 132.

Cheng, S. \& Tzeng, J. (2010). College Female and Male Heavy Internet Users' Profiles of Practices and Their Academic Grades and Psychosocial Adjustment. Cyberpsychology, Behavior,and Social Networking, 13(3), 257-262.

Çiftçi, H. (2018). Social Media Addiction among University Students. MANAS Journal of Social Studies, 7(4), 417-432.

Datareportal (2019). Digital 2019: Turkey, https://datareportal.com/reports/digital-2019-turkey

Reached date: 10.06.2020. 
Diker, E. \& Taşdelen, B. (2017). What Would Happen Without Social Media? A Qualitative Research on Social Media Addicted Youngsters' Opinions. International Peer-Reviewed Journal Of Communication And Humanities Research, 17, 189-206.

Felisoni, D. D. \& Godoi, A. S. (2018). Cell Phone Usage and Academic Performance: An Experiment. Computers\&Education, 117, 175-187.

Karakuyu, A. \& Ata, F. (2019). Investıgation of Some Variables of Nomophobias' of Associate Degree Students. The Journal of International Social Research, 12, 67.

Kuyucu, M. (2017). Use of Smart Phone and Problematic Of Smart Phone Addiction In Young People: "Smart Phone (Colic)" University Youth. Global Media Journal TR Edition, 7(14), $327-359$.

Noyan, C. O., Darçın, A, E., Nurmedov, S., Yılmaz, O. \& Dilbaz, N. (2015). Validity and Reliability of the Turkish Version of the Smartphone Addiction Scale-Short Version Among University Students. Anatolian Journal of Psychiatry, 16(1), $73-81$.

Pamuk, M. \& Atl1, A. (2016). Development of a Problematic Mobile Phone Use Scale for university students: validity and reliability study. Dusunen Adam The Journal of Psychiatry and Neurological Sciences, 29, 49-590.

Seo, D. G., Park, Y., Kim, M. K. \& Park, J. (2016). Mobile Phone Dependency and its Impacts on Adolescents' Social and Academic Behaviors. Computers in Human Behaviour, 63, 282-292.

Tavolacci, M.P., Meyrignac, G., Richard, L., Dechelotte P. Ve Ladner, J. (2015). "Problematic Use of Mobile Phone and Nomophobia Among French College Students", The European Journal of Public Health, 25(Suppl 3): 206.

Talan, T., Korkmaz, A. \& Gezer, M. (2016). A Study On Investigating The Mobile Phone Addiction Levels From The University Students. International Contemporary Educational Research Congress.

Yen. C.F., Tang. T. C., Yen. J., Lin. H., Huang. C., Liu. S., Ko. C., (2009) Symptoms of problematic cellular phone use, functional impairment and its association with depression among adolescents in Southern Taiwan, Journal of Adolescence, Volume 32, Issue 4

Y1lmaz, G., Şar, A. H. \& Civan, S. (2015). Investigation of Adolescent Mobile Phone Addiction by Social Anxiety Effect of Some Variable. Online Journal of Technology Addiction \& Cyberbullying, 2(4), 20-37. 